\title{
Liga Arab dan Demokratisasi di Dunia Arab
}

\section{Sugito}

Jurusan IImu Hubungan Internasional, Fakultas IImu Sosial IImu Politik, Universitas Muhammadiyah Yogyakarta

Ringroad Barat Tamantirto, Kasihan, Bantul 55183

Email: sugito@umy.ac.id

\begin{abstract}
Arab world never deserted from International discussions. It related to long drawn conflict in that region, such as conflict of Palestine and Israel, Iraq condition after US attack, also terrorism issues which alleged to this region. The Arab world became identical with a region which full of conflict and have no political certainty. On this condition, Arab League as institutional cooperation of countries in this region forced to have articulative roles.

Keywords: legitimacy, modernization, reformation, civil society, world government
\end{abstract}

\begin{abstract}
Abstrak
Dunia Arab tidak pernah sepi dari pembicaraan internasional. Hal ini berkaitan dengan konflik berkepanjangan di kawasan tersebut seperti konflik Palestina dengan Israel, kondisi Irak pasca penyerangan AS, dan juga isu-isu terorisme yang banyak ditudingkan ke kawasan ini. Dunia Arab menjadi identik dengan wilayah yang penuh konflik dan tidak memiliki kepastian politik. Dalam kondisi demikian, Liga Arab sebagai lembaga kerjasama negara-negara di kawasan ini, dituntut memiliki peran artikulatif.

Kata kunci: legitimasi, modernisasi, reformasi, masyarakat sipil, pemerintahan dunia
\end{abstract}

\section{PENDAHULUAN}

Selain masalah konflik yang kerap menyertai kehidupan politik, Dunia Arab juga mengalami kegalauan terhadap reformasi. Reformasi yang berlangsung selama ini selalu identik dengan revolusi, seperti yang terjadi di Irak, Suriah, Mesir, dan Lebanon. Di Republik tersebut, para pemimpinnya berupaya untuk menggantikan pola-pola otoritas tradisional yang terjadi pada sistem kerajaan dan nilainilai patriakal, kesucian, dan quasi-feudal yang berada di masyarakatnya dengan simbol dan mitos-mitos modern dan reformis. Dari beberapa republik tersebut, ada juga yang menjalani reformasi akibat tekanan pihak asing, seperti yang terjadi di Irak pada tahun 2003 yang lalu.
Reformasi tidak hanya berupa pergantian sistem pemerintahan dari monarki menjadi republik atau pemerintahan modern lainnya. Namun, reformasi di Dunia Arab kini telah menjadi isu demokratisasi kehidupan politik dan ekonomi masyarakat. Hal ini seiring dengan proses mobilisasi sosial yang terjadi di Dunia Arab sendiri dan juga akibat dari gelombang demokratisasi yang melanda semua negara, tidak terkecuali Dunia Arab.

Isu demokratisasi telah menjadi perhatian seluruh pemimpin Arab. Dalam KTT Liga Arab yang berlangsung 22 - 25 Mei 2004 di Tunis, Tunisia, ada beberapa agenda penting yaitu isu Palestina, Irak, reformasi di dunia Arab, dan restrukturisasi lembaga 
Liga Arab. Konferensi yang seharusnya dilaksanakan pada 29 - 30 Maret lalu, secara sepihak diundur oleh Tunisia dengan alasan terjadi perbedaan pendapat diantara sesama negara Arab soal isu substansial dan penting menyangkut reformasi di dunia Arab, khususnya masalah demokrasi, hak asasi manusia, pemberdayaan kaum perempuan, dan peran civil society. (Kompas, 2004).

Dalam tulisan ini akan berusaha dijawab beberapa pertanyaan penting, yaitu bagaimanakah sebenarnya kehidupan demokrasi di dunia Arab? dan bagaimana pula peranan yang dijalankan oleh Liga Arab dalam proses demokratisasi di dunia Arab?

\section{PEMBAHASAN}

\section{DEMOKRASI DI DUNIA ARAB}

Sebelum membahas demokrasi di dunia Arab, maka penulis akan mencoba menetapkan terlebih dahulu titik tolak untuk menentukan standar pengukuran penampilan demokrasi di sana. Tentu saja, yang akan diungkapkan adalah karakter utama demokrasi itu sendiri (principal features), karena tidak mungkin mengungkapkan semua elemen demokrasi. Selanjutnya kita akan melihat pula bagaimana regionalisme terjadi dan bagaimana peran organisasi regional bagi negara-negara anggotanya.

Dalam ilmu politik, dikenal dua macam pemahaman tentang demokrasi: pemahaman secara normatif dan pemahaman secara empirik (procedural democracy). Dalam pemahaman secara normatif, demokrasi merupakan sesuatu yang secara idiil hendak dilakukan atau diselenggarakan oleh sebuah negara dan ungkapan ini biasanya tertuang dalam konstitusi negara. Sedangkan demokrasi dalam artian empirik diperoleh para ilmuwan politik dari pengamatan praktik demokrasi di berbagai negara dan kemudian merumuskan demokrasi secara empirik dengan menggunakan sejumlah indikator tertentu (Gaffar, 2002:3-4).

Seorang ilmuwan politik yang banyak mengkaji demokrasi secara empirik, G. Bingham Powell, Jr., mempersyarakatkan sejumlah kriteria untuk melihat apakah demokrasi betul-betul terwujud dalam suatu negara. Kriteria tersebut adalah sebagai berikut:
1. The legitimacy of the government rests on a claim to represent the desires of its citizens. That is, the claim of the government to obedience to its laws is based on the government's assertion to be doing what they want it to do.

2. The organized arrangement that regulates this bargain of legitimacy is the competitive political election. Leaders are elected at regular intervals, and voters can choose among alternative candidates. In practise at least two political parties that have a change of winning are needed to make such choices meaningful.

3. Most adults can participate in the electoral process, both as voters and as candidates for important political office.

4. Citizens votes are secret and not coerced.

5. Citizens and leaders enjoy basic freedom of speech, press, assembly, and organization. Both established parties and new ones work to gain members and voters (Powell, Jr., 1982:3 dalam Gaffar, 2002:5-6).

Melihat dari aspek-aspek demokrasi yang disampaikan oleh Powell, Jr. nampak adanya semangat untuk meletakkan rakyat dalam kekuasaan yang besar. Dengan mekanisme pemilihan umum, rakyat diberikan hak untuk menjadi pemimpin sekaligus menjadi pemberi mandat kepada pemimpin yang akan terpilih nantinya. Selain itu, penghormatan yang tinggi atas hak-hak dasar rakyat, seperti kebebasan berbicara dan berkumpul menjadi bentuk dari pentingnya posisi rakyat dalam pemerintahan demokrasi.

Robert Dahl, seorang ilmuwan politik yang banyak menulis tentang demokrasi, memberikan tujuh indikator bagi demokrasi secara empirik:

1. Control over governmental decisions about policy is constitutionally vested in elected officials.

2. Elected officials are chosen and peacefully removed in relatively frequent, fair and free elections in which coercion is quite limited.

3. Practically all adults have the right to vote in these elections.

4. Most adults have the right to run for public offices for which candidates run in these elections. 
5. Citizens have effectively enforced right to freedom of expression, particularly political expression, including criticism of the officials, the conduct of government, the prevailing political, economic, and the dominant ideology.

6. They also have access to alternative sources of information that are not monopolized by government or any other single group.

7. Finally they have and effectively enforced right to form and join autonomous associations, including political associations, such as political parties and interest groups, that attempt to influence the government by completing in election and by other peaceful means. (dalam Gaffar, 2002:7).

Dari kedua ilmuwan tersebut, kita mendapatkan beberapa prasyarat suatu sistem politik dikatakan demokratis bila memiliki unsur-unsur akuntabilitas, dimana pemimpin memiliki kewajiban untuk bertanggung jawab kepada rakyat, rotasi kekuasaan secara periodik dan damai, rekrutmen politik terbuka bagi siapa saja yang memenuhi persyaratan menjadi pemimpin atau pejabat publik, pemilihan umum yang teratur, langsung, jujur, adil, dan bebas, serta adanya penghargaan pemerintah atas hak-hak dasar rakyatnya.

Sistem politik yang demokratik berupaya untuk mencari suatu identitas bersama di sekitar nilai-nilai kemasyarakatan. Sistem tersebut cenderung mempertahankan adanya keanekaragaman dan konflik. Rakyat tetap mempertahankan keterikatan-keterikatan mereka pada berbagai nilai-nilai primordial, sakral, dan personal serta tidak diharapkan untuk memberikan loyalitas mereka yang eksklusif dan menyeluruh kepada pemimpin, partai, atau negara. Tidak ada keortodokan ideologis yang akan menyebut oposisi terhadap pendapat-pendapat yang dominan sebagai pengkhianatan. Rakyat memberikan loyalitas mereka terhadap beberapa sumber (Andrain, 1992:258).

Charles F. Andrain, lebih lanjut menjelaskan bahwa dalam sistem yang demokratis, muncul rasa saling percaya diantara warga negara dan antara warga negara dengan pemerintah. Mereka juga menyadari adanya gagasan kesejahteraan umum dan berupaya untuk mewujudkannya. Mereka berperan serta dalam politik tidak hanya untuk kepentingannya sendiri, namun lebih dari itu juga untuk seluruh masyarakat, termasuk aneka ragam kelompok rasial, etnis, agama, dan regional. Intinya bahwa, identitas demokrasi yang ideal bertumpu pada "kesatuan dalam keanekaragaman".

Demokrasi di negara-negara Arab belum dapat tumbuh secara baik. Hal ini terutama terjadi di negaranegara monarki, seperti Arab Saudi, Kuwait, Oman, Bahrain, Qatar, Uni Emirat Arab, dan Jordania. Di negara-negara yang masih mendasarkan legitimasi pada ikatan-ikatan primordial, agama, dan budaya tersebut, sangat rentan terhadap modernisasi. Oleh karenanya di negara-negara monarkhi ini tidak lagi ditemui adanya struktur kekuasaan yang benar-benar tradisional melaikan "kerajaan yang termodernisasi" (modernizing monarchies).

Modernisasi di negara-negara monarkhi telah mengakibatkan munculnya "the king's dilemma". Samuel Huntington dalam bukunya Political Order in Changing Societies berpendapat bahwa disatu sisi, kekuasaan yang sangat sentralistis diperlukan untuk menjalankan pembaruan-pembaruan sosial, budaya, dan ekonomi, namun disisi lain sentralisasi tersebut telah mempersulit atau bahkan tidak mungkin bagi kerajaan tradisional untuk memperluas basis kekuasaannya dan menerima kekuasaan kelompokkelompok baru yang dihasilkan oleh modernisasi (Hudson, 1977:166). Fenomena inilah yang sampai sekarang ini terjadi di negara-negara monarkhi Arab.

Di Arab Saudi misalnya, kekuasaan politik sangat terpusat pada raja yang memegang jabatan-jabatan Kepala Dinasti Saudi, Perdana Menteri, Kepala Eksekutif, Imam Keagamaan tertinggi, Komandan Angkatan Bersenjata, dan Kepala Pengadilan (Aburish dalam Jatmika, 2000:72). Penguasa di negara ini memiliki kecenderungan kuat membatasi sesempit mungkin berlakunya nilai-nilai liberal, partisipasi politik rakyatnya, dan demokrasi. Guna membendung pengaruh medernisasi, Raja Saudi menempuh strategi akomodasi terhadap berbagai kekuatan tradisional dan berupaya menghidari pembentukan identitas nasional baru. 
Kemunculan kelompok-kelompok baru yang beraliran reformis di Arab Saudi, selalu mendapatkan penentangan dari penguasa. Kelompok-kelompok reformis yang banyak diilhami oleh kebangkitan gerakan-gerakan Islam, sering dianggap sebagai gerakan Islam fundamental atau teroris seperti yang menimpa kelompok pimpinan Osama Bin Laden. Upaya membatasi munculnya kelompok reformis juga dilakukan dengan memperkuat kelompok-kelompok tadisional untuk meredam pengaruh kaum reformis yang kebanyakan kaum intelektual dan golongan menengah di masyarakat umum.

Permasalahan demokrasi juga dialami oleh negaranegara Republik Arab, yaitu Mesir, Suriah, Irak, Lebanon, Yaman, dan Palestina. Apabila di negaranegara monarkhi, pengusa berupaya untuk mempertahankan dan mencari legitimasi dengan mempertahankan pola tradisional dan menghubungkannya dengan modernitas, maka para pemimpin di negara-negara Republik berupaya untuk mempertahankan dan mencari legitimasi dari sumbersumber modern dan menghubungkannya dengan polapola otoritas tradisional. Oleh karena itu, di dalam negara-negara ini sering kita jumpai adanya procedural democracy, seperti pembagian kekuasaan (eksekutif, legislatif, dan yudikatif), partai politik, dan pemilihan umum. Namun disisi lain, kita juga akan menjumpai kuatnya nilai primordial, keagamaan, dan sumbersumber legitimasi tradisonal, seperti karisma, keturunan, dan agama.

Ada kecenderungan bahwa para pemimpin negaranegara republik yang revolusioner untuk bersikap otoriter. Hal ini dilakukan untuk meredam sentimensentimen etnisitas yang sering memunculkan konflik horisontal bahkan vertikal. Dengan banyaknya kelompok-kelompok etnis, agama, dan regional yang masih berpegang kukat pada nilai-nilai tradisionalnya, serta belum disepakatinya nilai-nilai baru, maka salah satu cara untuk menciptakan kohesi masyarakat adalah dengan cara pemaksaan melalui kekuatan militer. Inilah yang dilakukan oleh Saddam Hussein di Irak dan Hafiz Al Assad di Suriah.

Meskipun partai politik ada dalam negara-negara
Republik Arab, namun digunakan oleh penguasa sebagai alat pelegitimasi kekuasaan. Munculnya partaipartai sosialis seperti di Irak dan Suriah yang sangat hirarkhis dan sentralistis, memudahkan penguasa untuk melakukan doktinasi ideology dan penggalangan massa. Oleh karena itu, sering kita temui munculnya partai-partai dominan atas rekayasa penguasa yang susah untuk dikalahkan dalam pemilu.

Upaya-upaya penguasa untuk mengkaitkan antara masa saat ini (modern) dengan masa lampau nampak dalam pengakomodasian kelompok-kelompok etnis atau agama yang ada dalam satu negara ke dalam lembaga politik. Di Lebanon, misalkan terjadi sharing kekuasaan antara Sunni, Syiah, Katolik Yunani, Katolik Orthodox dan Druze.

Beberapa kasus di negara-negara Arab baik monarkhi maupun republik di atas, memberikan kesimpulan pada kita bahwa demokrasi tidak bisa tumbuh baik di dunia Arab karena beberapa faktor:

1. Elit penguasa yang tidak mau untuk berbagi kekuasaan dengan kelompok-kelompok baru yang muncul seirig dengan modernisasi.

2. Masih kuatnya nilai-nilai primordialisme dan belum terciptanya nilai-nilai baru sehingga muncul rasa saling tidak percaya antara satu kelompok dengan kelompok yang lain.

3. Berkaitan dengan tidak adanya rasa saling percaya antar kelompok masyarakat itu, maka kemudian pemerintah bersikap otoriter untuk menciptakan kohesi masyarakat.

\section{PERAN LIGA ARAB DALAM DEMOKRATISASI}

Liga Arab termasuk dalam organisasi internasional yang memiliki tipologi regional intergovernmental organization dimana keanggotaannya terdiri atas negara-negara yang berada dalam suatu kawasan (Rourke, 1986:302) Sementara itu, bila dilihat dari bidang kerja samanya, Liga Arab merupakan organisasi yang multipurpose dengan tujuan-tujuan yang meliputi politik, ekonomi, dan sosial.

Ada beberapa alasan bagi negara untuk mendirikan atau bergabung dalam suatu organisasi internasional. Pertama, organisasi internasional dijadikan sebagai 
instrumen politik luar negeri. Dalam hal ini, negaranegara anggota saling berdebat dan mendesakkan kepentingan negaranya untuk menjadi keputusan bersama. Kedua, bagi negara-negara yang tidak memiliki hubungan bilateral dengan suatu negara secara intensif, dapat memanfaatkan organisasi internasional untuk memperoleh informasi-informasi tentang negara yang bersangkutan. Hal ini bisa dilakukan melalui akses data yang selalu tersedia di Sekretariat Jenderal atau juga bisa kontak langsung dengan perwakilan negara di Majelis Umum.

Terakhir, organisasi internasional menjadi sarana untuk memaksa prilaku negara-negara anggotanya. Melalui setting agenda internasional dan nasional, organisasi internasional dapat mempengaruhi pembuatan kebijakan nasional negara-negara anggotanya. Selain itu, upaya mendesak prilaku negara ini juga dapat dilakukan melalui pembentukan prinsipprinsip, norma-norma, dan aturan-aturan yang dapat mempengaruhi negara anggota untuk mematuhinya bila ingin mendapatkan keuntungan dari keanggotaannya. Bagi organisasi yang memiliki alat pemaksa, maka dapat pula dilakukan melalui embargo kepada suatu negara yang melanggar ketentuan organisasi (Mingst, 1999:242-243).

Organisasi internasional juga memiliki tujuantujuan yang berbeda-beda yang meliputi pembentukan pemerintahan dunia (world government), kerja sama menyeluruh, kerja sama fungsional, dan/atau keuntungan secara politis (Rourke, 1986:307). World government dapat tercipta apabila negara-negara anggota menyerahkan semua atau sebagaian besar kedaulatannya kepada organisasi yang mereka bentuk. Organisasi ini akan diberikan kelangkapan wewenang untuk membuat, menegakkan, dan ajudikasi suatu peraturan. Struktur yang akan muncul nantinya adalah federal, dimana organisasi menjadi pusat kekuasaan dan negara-negara anggota bertindak sebagai negaranegara bagian yang hanya melakukan tindakan administratif saja.

Banyak ilmuan yang mengkritik tentang world government ini. Mereka lebih cenderung melihat organisasi internasional sebagai sarana kerja sama internasional dari pada meletakkan negara-negara anggotanya dibawah subordinasi otoritas global. Organisasi internasional dapat menjalankan peran netral untuk mediasi dan konsiliasi dari pada koersi. Tujuannya disini adalah untuk mengarahkan dan membiarkan negara-negara anggota untuk bekerja bersama.

Pandangan semacam itu hampir sama dengan orangorang fungsionalis yang melihat organisasi internasional sebagai unit kerja sama fungsional. Mereka percaya bahwa dari kerja sama pada bidang yang spesifik, biasanya bukan politik, akan menumbuhkan rasa saling percaya satu negara dengan yang lainnya. Dari sinilah kemudian muncul kerja sama di bidang lainnya yang lebih luas dan tinggi (high politic). Pandangan kaum liberal yang "bottom up" dalam memandang kerja sama internasional ini berlawanan dengan para penggagas federalism yang meyakini kerja sama berproses secara "top down".

Banyak pula yang menilai bahwa organisasi internasional sebagai sarana untuk memaksimalkan kepentingan nasionalnya dalam tatanan internasional. Hal ini tidak bisa dipungkiri melihat prilaku negaranegara yang tergabung dalam suatu organisasi yang saling memaksakan kepetingannya baik dengan bekerja sama maupun dengan membatasi kepentingan negara lainnya, seperti yang terjadi di PBB dan organisasi lainnya.

Liga Arab muncul setelah adanya inisiatif dari Inggris pada tahun 1942 untuk menggalang kekuatan negara-negara Arab dalam menghadapi kekuatan negara-negara poros. Namun demikian, baru pada tahun 1945 Liga Arab berdiri dengan dua agenda utama ketika itu yaitu pembebasan negara-negara Arab yang masih dibawah penjajah dan mencegah minoritas Yahudi di Palestina untuk mendirikan negara Yahudi.

Berdirinya Liga Arab diwarnai oleh kepentingan negara-negara anggotanya untuk mempererat hubungan diantara negara-negara yang mayoritas berbahasa Arab. Dengan pendirian Liga ini, diharapkan negara-negara anggotanya dapat melakukan koordinasi kebijakan dan dapat mencapai kemakmuran bersama. Sejak berdirinya hingga saat ini, Liga Arab telah 
beranggotakan 22 negara termasuk Palestina yang diakui kedaulatannya.

Melihat dari sejarah berdirinya Liga Arab, organisasi ini muncul bukan dari kerja sama fungsional diantara para pendirinya, namun diawali dari kerja sama politik. Dalam perkembangnnya pun, negara-neagra anggota belum memperlihatkan kemauannya untuk menjadikan Liga Arab sebagai lembaga yang memiliki otoritas diatas mereka. Hal ini tercermin dari mekanisme pengambilan keputusan, dimana diputuskan dengan mayoritas suara dan hanya mengikat bagi yang menyetujuinya. Selain itu secara nyata Liga Arab gagal untuk menerapkan sanksi bagi anggotanya yang melanggar seperti Irak saat menginvasi Kuwait.

Liga Arab lebih sering menampakkan dirinya sebagai sarana bagi negara-negara anggotanya untuk melaksanakan politik luar negerinya. Dalam pengertian ini, negara-negara anggotanya lebih sering memanfaatkan Liga untuk mendesakkan kepentingannya untuk menjadi keputusan bersama dan menarik diri dari keputusan jika hal itu tidak sesuai dengan kepentingannya. Banyak contoh kasus seperti Invasi Irak ke Kuwait dan juga terpecahnya sikap negara-negara anggota dalam permasalahan invasi AS ke Irak tahun 2003 lalu. Terakhir kali hal ini nampak ketika terjadi keengganan dari para pemimpin negara-negara anggota untuk mengagendakan reformasi pada KTT Liga Arab yang terakhir di Tunis 22 - 25 Mei 2004.

Kekurangberhasilan Liga Arab di bidang politik dapat disebabkan oleh berbagai macam sebab. Akan tetapi yang tampak sekali adalah adanya perbedaan antarnegara arab itu sendiri. Pada masa perang dingin, terjadi perbedaan pandangan terhadap negara-negara Barat dengan negara-negara komunis. Perbedaan pandangan ini berlanjut ketika isu demokratisasi yang melanda hampir seluruh belahan dunia, juga dirasakan oleh dunia Arab.

Isu yang terakhir, yaitu mengenai permasalahan agenda reformasi yang termasuk di dalamnya adalah demokratisasi, baik itu di negara-negara dunia Arab maupun di dalam tubuh organisasi Liga Arab, telah mendapatkan pandangan yang beragam. Bagi negaranegara monarkhi, reformasi menjadi isu yang sensitif untuk dibicarakan berkaitan dengan pengorganisasian negara yang masih mendasarkan legitimasi kekuasaan berdasarkan pada ikatan-ikatan tradisional terutama keturunan dan agama. Bagi mereka, persaratan demokrasi yang mengharuskan adanya rekrutmen politik secara terbuka dan terjadinya rotasi kekuasaan secara rutin tidak dapat dijalankan. Selain itu, demokratisasi yang berarti pemberdayaan rakyat dalam berpolitik akan menjadi ancaman bagi legitimasi mereka yang telah didapatkan dari kepatuhan rakyat terhadap pengusa atas factor-faktor suci, keturunan, dan agama. Oleh karena itu, sikap negara-negara monarkhi akan selalu menentang adanya demokratisasi.

Bagi negara-negara Republik yang cenderung revolusioner dan sosialis, demokratisasi juga dipandang sebagai ancaman yang akan mengganggu kekuasaannya. Pemerintahan yang cenderung otoriter dengan kekuasaan yang ditopang oleh faktor karisma, Partai yang bercorak Sosialis, dan militer yang kuat, akan sangat rentan dengan isu demokratisasi dimana disyaratkan adanya penguatan peran rakyat sebagai pemegang kedaulatan tertinggi dalam negara. Kekuatan represif seperti yang nampak di beberapa negara Republik seperti Irak dan Suriah dan consensus atau minimal berupaya unt, berarti pula seperti Arab Saudi dalam menyelesaikan konflik di masyarakat, akan menjadi cara yang ditabukan dalam rejim yang demokratis. Oleh karena itu, didalam pemerintahan yang otoriter, demokratisasi mendapatkan resistensi yang kuat dari para elit penguasa.

Bagi beberapa negara Republik yang moderat seperti Lebanon, Sudan, Mesir, dan Yaman, permasalahan demokrasi lebih berakar pada tingkat kemajemukan penduduk, baik dari segi agama, etnis, dan region. Perbedaan yang diperkuat oleh ikatanikatan primordialisme akan menyulitkan terjadinya konsensus di dalam masyarakat. Padahal di dalam masyarakat yang demokratis harus tercipta adanya sikap moderat dan saling mempercayai agar dapat tercapai penyelesaian konflik secara damai. 
Ketidakberhasilan Liga Arab dalam bidang politik pada umumnya, juga disebabkan oleh komitmen anggota yang kurang kuat untuk memberikan kekuatan legal pada organisasi. Negara-negara anggota sejak awal didirikan juga tidak memiliki keinginan untuk menjadikan Liga Arab sebagai suatu uni penuh. Liga Arab tidak memiliki kekuatan berupa kekuasaan yang sepenuhnya untuk memaksakan setiap keputusan yang telah diambil dalam sidang-sidangnya (Rudy, 1993:113). Akibatnya Liga Arab kurang berperan dalam usaha untuk mencapai sasaran-sasarannya berupa terciptanya kedamaian dan kemajuan di dunia Arab.

Rendahnya komitmen negara anggota untuk menyerahkan kedaulatannya yang lebih besar lagi dalam bidang politik juga menjadi penyebab kenapa isu reformasi di tubuh Liga mengalami hambatan. Tarik ulur kepentingan negara-negara anggota telah menjadikan fungsi Liga sebagai tempat bargaining kebijakan-kebijakan luar negeri, dari pada menjadi tempat koordinasi kebijakan. Dengan demikian, Liga memang disengaja untuk tidak diberikan kewenangan yang lebih besar dalam bidang politik.

Liga Arab lebih dekat kita pahami sebagai organisasi regional dimana negara-negara anggota sebagai policy influencer yang lebih dominan dari pada Sekretaris Jenderal dan stafnya dalam pengambilan kebijakan organisasi. Dalam kondisi yang demikian, negara-negara anggota memberikan batasan kekuasaan yang sangat sempit dan ketat terhadap Sekjen. Oleh karenanya, praktis seorang Sekjen tidak bisa mengeluarkan kebijakan tanpa persetujuan anggota berdasarkan prosedur pengambilan suara yang telah ditentukan. Keengganan negara-negara untuk memberikan keleluasaan kekuasaan kepada secretariat tetapnya biasanya merupakan akibat dari ketidakpercayaan terhadap satu sama lain (antar negaraa anggota), bukan ketidak percayaan kepada secretariat (Coplin, 1987, 209). Inilah yang terjadi di Liga Arab dimana karena ketidakpercayaan satu sama lain, negara enggan memberikan kekuasaan yang lebih besar kepada secretariat tetap di Kairo, Mesir.

Namun dengan keterbartasan kekuasaan tersebut,
Sekjen tetap memiliki beberapa keuntungan yang dapat ia gunakan untuk mempengaruhi pengambilan keputusan dan juga kemampuan personalnya untuk menjadi mediator dalam suatu konflik. Dengan berbekal kemampuan diplomasi yang telah ia jalani sebagai Menteri Luar Negeri Mesir dan juga keterkenalan beliau sebagai diplomat yang karismatik di dunia Arab, Amr Mousa mampu mengajak negaranegara anggota yang berbeda pandangan dalam isu reformasi untuk tetap mau melakukan KTT di Tunisia tahun 2004 meskipun mengalami kemunduran jadwal.

\section{KESIMPULAN}

Isu demokratisasi yang sarat dengan pemikiranpemikiran liberal Barat, kini telah menjadi perbincangan politik yang panas di dunia Arab. Hal ini berkaitan dengan resiko yang harus ditanggung oleh para penguasa ketika isu demokratisasi ini dijalankan oleh mereka atau rakyat menuntut semakin kuat adanya proses tersebut. Bagi para penguasa monarkhi Arab yang mendapatkan kekuasaan berdasarkan keturunan dan mempertahankannya dengan cara-cara tradisional, akan kehilangan kekeuasaannya jika kemudian mereka membuka pintu demokrasi yang mensaratkan adanya rotasi kepemimpinan melalui mekanisme Pemilu dan rekrutmen politik terbuka. Namun di sisi lain, kemajuan yang telah dinikmati rakyatnya, membuat mereka semakin sadar akan hakhak kebebasan sebagai manusia mandiri dan menuntut untuk berpartisipasi lebih luas.

Bagi penguasa di negara-negara Republik Arab, masalah yang dihadapi adalah bagaimana demokrasi untuk tidak merusak atau menghilangkan sumbersumber legitimasi tradisional seperti karisma, agama, dan ikatan-ikatan primordial. Oleh karena itu, ketika nilai modern belum sepenuhnya muncul dan nilainilai tradisional belum juga sepenuhnya ditinggalkan, yang muncul sebagai kekuatan efektif untuk mencapai konsensus adalah kekuatan represif yang dijalankan oleh militer.

Sebagai organisasi regional, Liga Arab tidak bisa berbuat lebih baik ketika berhadapan permasalahan- 
permasalahan politik termasuk didalamnya isu demokratisasi. Dengan kewenangan terbatas yang diberikan oleh negara-negara anggota, Liga Arab tidak lebih sebagai sarana untuk memperjuangkan kepentingan nasional dari pada kepentingan kolektif dunia Arab. Dalam posisi yang demikian, Liga menjadi lemah untuk menghasilkan keputusan yang bulat dan mengikat bagi anggotanya.

Kaitannya dengan isu demokratisasi, Liga Arab tidak mampu untuk menghasilkan keputusan. Hal ini disebabkan oleh perbedaan pandangan yang tajam antara anggota dalam mensikapi isu tersebut. Sekali lagi, karena hanya sebagai sarana untuk memperjuangkan kepentingan nasionalnya sendirisendiri, maka Liga Arab tidak mampu untuk menemukan langkah bersama dalam mensikapi isu demokratisasi ini.

\section{REFERENSI}

Rudy, Teuku May., Administrasi dan Organisasi Internasional, Bandung, PT Eresco, 1993.

Mingst, Karen., Essentials of International Relations, New York, WW. Norton \& Company, 1999.

Hudson, Michael C., Arab Politics: The Search for Legitimacy, New Haven and London, Yale University Press, 1977.

Jatmika, Sidik., AS Penghambat Demokrasi, Yogyakarta, Bigraf, 2000.

Andrain, Charles F., , Kehidupan Politik dan Perubahan Sosial (diterjemahkan oleh Luqman Hakim), Yogyakarta, Tiara Wacana, 1992.

Coplin, William D., Pengantar Politik Internasional: Suatu Telaah Teoritis (diterjemahkan oleh Marsedes Marbun), Bandung, CV Sinar Baru, 1992.

Jacobson, Harold K., Network of Interdependence: International Organizations and the Global Political System, New York, Alfred A. Knopf, 1979.

MEDIA

Kompas, 23 Mei 2004. 